\title{
INTRODUGTION
}

\section{WHEN THE BEES FLEW...}

\section{Historiography}

Everyone who has visited Rome will have noticed the bees that, in sometimes buzzing profusion, cover the surfaces of churches, fountains, palaces and, indeed, of every object imaginable, whether they be executed in cream-coloured travertine, highly polished marble, gilded bronze or glowing paint. Gregorio Leti, an influential and widely read I7th-century critic of the papacy, told his readers he had counted some twenty thousand bees both in the capital and in the other cities of the Papal States. ${ }^{1}$ They are the Barberini bees, the heraldic emblem of a family who produced Maffeo Barberini (I568-I644), who, as Urban VIII (I623-I644), became the longest-reigning pope of the i 7 th century.

Remarkably, but for a few excellent exceptions, 2oth-century historiography has produced no in-depth studies, biographical or otherwise comprehensive, of the early modern popes. Of course, Von Pastor's I920's, epochal 'History of the Popes' provides monumental, mostly book-length treatments of each individual pontiff. ${ }^{2}$ However, not only is Pastor's work obviously dated as well as, inevitably, biased, also the very existence of his extensive essays seems to have frightened modern historians; only few have ventured to re-evaluate his objects and his approach, and to formulate questions he, as a learned Prussian and a child of his time, simply did not ask.

However, it must be stated clearly that the following chapters do not presume even to begin to fill this gap for the pontificate of the one pope on whom I have chosen to concentrate. Yet, I do hope to contribute - in a small way, but from a much- needed multi-disciplinary point of view - to the study of some neglected but in my view essen-

\footnotetext{
${ }^{1}$ G. Leti, Il nepotismo di Roma (Amsterdam i667), Vol. I, 208, 228.

2 The best general treatment still remains: L. von Pastor, Geschichte der Päpste Pastor, o.c., Vol. XIII, I+2, Zeitalter der Katholischen Reformation und des Dreissigjahrigen Krieges. Gregor XV und Urban VIII (Freiburg I928-1929). To be cited as: Pastor.
} 
tial and interrelated aspects of papal policy during the Baroque period. Departing from my 1983 Ph.D.-thesis on the socio-cultural history of the Church's institutions in the 17 th century, ${ }^{3}$ I have set out, in this study, to integrate these earlier interests into the broader context of cultural history. Thus, I hope to add to recent studies whose authors have provided valuable new insights into various aspects of the period, especially Peter Burke, Patricia Waddy, John Beldon Scott, Laurie Nussdorfer, Marcus Völkel, Sebastian Schütze, Frederic Hammond and Bert Treffers, even though my focus is rather different and I find I cannot always agree with them. ${ }^{4}$

\section{Sources}

As will be evident from the notes, that contain full bibliographic references, this study does, of course, take into account the large body of (modern) scholarly literature both on Barberini Rome, the papacy and the wider issues of politics and culture I propose to address. However, basically this book is built on the sources produced by the people I have put centre-stage. Indeed, many of my questions originated in my fascination with these sources rather than in the literature. Now, an exhaustive list of all individual documents cited would be meaningless: it would simply consist of the many hundreds of volumes of archival and other manuscript material I haven consulted, often containing as many as several hundreds of individual documents, each. It seems, however, useful to outline the structure of the material.

In view of the complex interaction, over more than a millennium, of those two rather disparate institutions - the Roman Catholic Church

3 P.J.A.N. Rietbergen, Pausen, Prelaten, Bureaucraten. Aspecten van de Geschiedenis van het Pausschap en de Pauselijke staat in de I7e eeuw (Nijmegen I983).

${ }^{4}$ P. Burke, The Historical Anthropology of Early Modern Italy (Cambridge 1987); P. Waddy, Seventeenth-century Roman palaces: Use and the Art of the Plan (New York 1990); J.B. Scott, Images of Nepotism. The Painted Ceilings of Palazzo Barberini (Princeton I99I); L. Nussdorfer, Civic Politics in the Rome of Urban VIII (Princeton 1992); M. Völkel, Römische Kardinalshaushälte des 17. Fahrhunderts. Borghese, Barberini, Chigi (Tübingen I993); S. Schütze, 'Urbano inalza Pietro, e Pietro inalza Urbano. Beobachtungen zu Idee und Gestalt der Ausstattung von Neu-Sankt Peter unter Urban VIII', in: Römisches Fahrbuch der Biblioteca Hertziana, 29 (1994), 213-287; Fr. Hammond, Music and Spectacle in baroque Rome. Barberini Patronage under Urban VIII (New Haven 1994); B. Treffers, Een Hemel op Aarde. Extase in de Romeinse Barok (Amsterdam 1995). 
and the Papal States - the documentary situation in Rome is equally complex. Simplifying matters slightly, it can be sketched as follows.

On the one hand, the archives pertaining to the government of the 'universal' Church are preserved in the so-called "Archivio Segreto Vaticano" (ASV), one of the largest archives in the world; it is still kept in the Vatican Palace itself. Contrary to what the name seems to suggest, its holdings are no more secret than the archives of any global organization or, indeed, of any (Western) state. Ordered, basically, along the lines dictated by the Church's institutional structure and needs, those who want to find the documents pertaining to a particular pontificate, as, in my case, the reign of Urban VIII, have to go through the inventories that, sometimes in detail, sometimes only sketchily, list the countless thousands of documents produced by each and any of the dozens of departments and sub-departments that made up the papacy's central bureaucracy.

Also, given the fact that, from the late 15 th to the early i8th centuries, most popes decided to involve one or more of their closest relatives in the management of Church affairs, wanting to know more about Cardinal Francesco Barberini as Cardinal-Secretary of Statebasically the Church's prime minister-cum minister of foreign affairs-I could expect to have to consult the huge archives of, for example, the State Secretariat. For his diplomatic missions to Spain, I had to see the archives of the papal embassy, or "nunziatura", in Madrid, et cetera. In assembling data from these departmental archives, I was able to flesh out chapter III, on Francesco's life.

On the other hand, the popes not only served as supreme pontiff, ruling the Church, they also governed the so-called "Patrimonium Petri', their 'temporal state' or, in short, the Papal States - the plural resulting form the fact that over time several formerly independent principalities had been included in it-, which, from the mid-fifteenth to the mid-nineteenth century, equalled the better part of Central Italy. This medium-sized kingdom which, or so the popes argued, safeguarded their political independence in the midst of and vis-à-vis the increasingly competitive and combative states of Europe, also furnished a considerable part of their income. If only to guarantee an uninterrupted tax-flow, their state had to be as well-governed as their Church. Consequently, the Vatican was not only the seat of the Church's central management, it also was the place where the "Stato Pontificio" was administrated. Besides the 'Congregations', or ministries specifically responsible for Church affairs, there were a number that took care 
of, e.g., papal finance - amongst others the "Camera Apostolica" — and other aspects of temporal government, such as the Congregation of the "Buon Governo", as well as a number of courts of high justice.

Since the post-medieval popes involved their family in the government of the Papal States as well, in searching for material documenting the official functions of the various members of the Barberini family, I also had to go through the archives of these ministries. Thus, in the archives of the "Camera Apostolica", I found some of the papers that enabled me, in chapter IV, to reconstruct the ceremonies of the reception of the imperial ambassador in 1637 .

Alas, by and large the records of the Papal States are not kept in the Vatican any more. Since the I870's, after the new state of Italy had been founded, the archives of the now former Papal States, containing tens of thousands of volumes, in their entirety have been transferred to the Italian state archives (Archivio di Stato di Roma, ASR), documenting, as they obviously did, part of the territory of the new state and its history. They can now be consulted - though not, one must admit, with the facility one would expect-either in the historic premises of the socalled "Palazzo della Sapienza", the former papal university, or in the new buildings at Rome's EUR-quarter.

Since the Italian government, in the I87os, seized most of the material possessions of the Church — such as, e.g., the Italian monasteriesall documents pertaining to these religious foundations were confiscated, too. Consequently, though one would, really, assume the archives of abbeys, churches and convents to be part of the Church's central archives in the ASV, they actually have to be looked for in the ASR. It is there that I found, by chance, the hundreds of documents I used to reconstruct the 'iconomachia' of the Bare Feet in the Augustinian Order, in chapter V. Yet, to discover whether the Barberini played any role in this fascinating case of propaganda politics, I had to return to the ASV, since, after all, any involvement of Pope Urban and his nephew in this case would have been part of government policy on the level of the Church as well.

However, as I discovered when I first started studying the history of the papacy, in Rome nothing is ever really simple. Indeed, historians addressing Roman history from the later Middle Ages onwards, are confronted with a decidedly complicating factor.

Since the late $5^{\text {th }}$ century, it was very common indeed for (upper echelon) papal bureaucrats to either keep copies of all their official papers, or, sometimes, to even simply preserve the better part of their 
original administration at home, in their family palace that, often, served as their office as well. Not uncommonly, such papers then ended up in the family archive, to be inherited by future generations, or to be thrown away by them. Given the importance of, especially, the archives of 'papal families' - those who produced both a pope and, in consequence of the practice of 'nepotism', one or more high-ranking papal administrators - any researcher delving into early-modern Roman history has to find out the whereabouts of the family papers pertaining to the pontificate(s) he studies.

Luckily, one way or another many of these family archives and manuscript collections have ended up in the Vatican after all. However, due to problems of, both, historical methodology and staffing, they have not been integrated in the "Archivio Segreto", though that might save researchers quite a bit of work indeed. Instead, they have been added as separate collections to the 'manuscript department' of the "Biblioteca Apostolica Vaticana" (BAV), in short the Vatican Library that, like its archival counterpart, is still situated in the Vatican Palace and is as open to the public as the archives are.

In the case of the Barberini family, their manuscript collections - the more than twenty thousand volumes of the so-called "Manoscritti Barberiniani Latini" - now form part of the BAV (BAV, BL). They include most of Pope Urban's private and official papers before he ascended the papal throne, amongst them the manuscripts of his poems, that inspired me to write chapter II. They also contain all of the remaining private and official papers of his relatives, including the hundreds of volumes recording the life and times of Cardinal Francesco Barberini. There, I found the letters and papers that allowed me to reconstruct Francesco's early days, his upbringing and his first years as his uncle's closest adviser, including the majority of documents that went into the writing of chapter III, as well as, quite luckily, some of the papers that proved his and Urban's involvement in the 'Case of the Bare Feet', analysed in chapter V. The Barberini Manuscripts also contain the Cardinal's extensive correspondences with such of his own collaborators as, e.g., his librarian Lucas Holstenius, highlighted in chapter VI. They amply illustrate Francesco's involvement in the life and works of the Orientalist scholar Abraham Ecchellen, described in chapter VII, as well. Moreover, precisely because Holstenius bequeathed to Barberini his own extensive manuscript collection, the learned German's other letter books - again, dozens of volumes - as well as the papers recording his own many official functions in the Church have been 
preserved amongst the "Barberiniani Latini", too. However, because of Ecchellen's and Holste's relations with France, and with French scholars, I had to consult some of the manuscript collections of the Bibliothèque Nationale in Paris as well.

Over the centuries, the papal families, enriched often beyond expectation by their papal uncles and their cardinal-nephews, obtained vast estates and other riches. The papers relating to their administration obviously made up the bulk of their family archives proper. In the case of the Barberini Archives - a huge mass of hundreds of weighty account books (some measuring as much as I00x45 $330 \mathrm{~cm}$ ), of grand ledgers, of bundles of business letters, et cetera - the researcher is, again, lucky in that they, too, now are part of the Vatican Library (BAV, Archivio Barberiniano, or AB). Though this is, in a sense, a highly unusual arrangement - normally a library, though it often contains a manuscript collection, does not double as an archive - the Vatican was able to acquire the Barberini Archives in the early 2oth century and wisely availed itself of the opportunity, not bothering about traditional rules of division and management. In the "Archivio Barberiniano", I discovered most of the documents that helped me reconstruct the construction and decoration of the Barberini family chapel in Sant'Andrea della Valle, as presented in chapter I. Yet, without the additional documentation found in the Barberini Manuscripts, the story would have been much the poorer.

Besides being based on all this archival and manuscript material, this study also relies on and refers to many i6th- and izth-century printed books, as, for example, the printed versions of Pope Urban's poems used in chapter II, the dozens of books published under the auspices of his nephew Cardinal Francesco cited in the Epilogue, the books written by the scholars attached to the various members of the Barberini family as used in chapters VI and VII, et cetera. Since, effectively, the papal library, i.e. the Vatican Library, was a copyright library, over the centuries it has come to hold hundreds of thousands of volumes, including many of the ones I have used. Moreover, though the Barberini family created a remarkable private library in its palace at Quattro Fontane - now Rome's museum of early modern art-, in the end that collection, too, including the beautiful Baroque scaffolding, was incorporated in the Vatican Library.

However, contrary to what one would think, in the i6th, I7th and I8th centuries many books were not printed at all, but existed only in one or more manuscript copies. To study these, or, indeed, to scru- 
tinize the original, manuscript version of many a printed book, one has to (re-)turn to the Vatican manuscript collections - in this case not only the "Manoscritti Barberiniani Latini", but also the "Manoscritti Chigiani" (BAV, Manoscritti Chigiani), the "Ottoboniani Latini" (BAV, Ottoboniani Latini) and the "Manoscritti Vaticani Latini" (BAV, Vat. Lat.), to cite but three of the many other major collections, each comprising thousands of manuscript volumes.

\section{Problems: power, religion and cultural policy in Baroque Rome}

The pontificate of Pope Urban VIII, the man who was baptized Maffeo Barberini in 1568 , lasted for 2I years, from his election to the papacy in 1623 to his death in I644. Thus, he became the embodiment of the Church of Rome and of the Papal States, that fascinating combination providing the researcher with an equally fascinating problem: how to analyse and comprehend an organization and a state ruled by a prince who combined the powers temporal and spiritual within an elective monarchical system, resulting in a situation that was unique in Europe. ${ }^{5}$ I have started from the assumption that, upon this stage, the 'grand theatre of the world' as Rome liked to define itself, the manifestations of culture could not but be complex and often contradictory.

When a new pope assumed the 'power of the keys' - the symbol of St. Peter's - he became the keystone of a structure that was seemingly immutable with the age-old traditions of the Roman Catholic Church that posed itself universal in place and time. At the same time, it was surprisingly flexible, functioning within a constantly changing economic, political and, from the early i6th century onwards religious setting and therefore forced to always absorb, albeit slowly, new ideas. Indeed, in itself the very process that enabled a person to reach the papacy implied participation in a system that required pairing a dogged adherence to accepted values to a certain originality of mind that yet would not offend the electors, the members of the College of Cardinals convened in a conclave, and the various factions that backed and

${ }^{5}$ I have dealt extensively with the structure of papal monarchy and the Papal States in: Rietbergen, Pausen, o.c., 'Introduction', and Chapter II. One should also consult: P. Prodi, Il Sourano Pontefice, un corpo e due anime: la monarchia papale nella prima età moderna (Bologna I982). 
often outright instructed them: the princes of (Catholic) Europe and the lobbies and pressure groups within the Church itself.

Once elected, a pope, of course, inherited all those traditions, theological, religious and liturgical as well as political and social: a pope inherited a complex culture, which had formed him as much as he was, often, able to form it himself. Prudent continuity in manipulating this culture was as essential to uphold his power as was judicious innovation of a wide range of traditions. Moreover, each pope sought to make and, preferably, leave his mark in Rome, not only in establishing his family in the forefront of society, but also in creating lasting monuments that, though they might strike both his contemporaries and posterity as testimonies to his own glory, were meant to proclaim the glory of Holy Church as well. And indeed, to the numerous visitors to this town that liked to think of itself as the Urbs, 'The City' par excellence, from humble pilgrims to haughty ambassadors, these monuments, whatever their nature and manifestation, soon lost their personal connotations, blending into one vision of a city truly 'eternal'. For it was a city that constantly remade itself, like a phoenix rising from its ashes. Using not only the old materials but also the old idea of the city itself, and the innumerable ideas it had generated over time, it wove a web of ideological links that made it the reflection on earth of the heavenly Jerusalem, the City of God. ${ }^{6}$

To this city, the Barberini came, a Florentine family who reached the apogee of power through their wise investment in and the good luck of one of their members, Maffeo Barberini, who, in i623, became Pope Urban VIII. Many people, scholars not excluded, will almost automatically associate the Barberini name with the most blatant manifestations of papal nepotism. Surely, however, far too much naively negative significance has been attached to this phenomenon, almost as if the pontificate of Urban VIII were a surviving act staged solely for the benefit of the Barberini family's power and prosperity. ${ }^{7}$ Rather than 'condemn' it, we should see it as a major instrument of power, to be understood against the background of the urgent political and psychological demands posed upon the 'ruling family' by the elective monarchy that was the papacy. ${ }^{8}$ In short, we should see it as a cultural phenomenon

\footnotetext{
${ }^{6}$ Cfr. P.J. Rietbergen, De retoriek van de Eeuwige Stad: Rome gelezen (Nijmegen 2003).

${ }^{7}$ As, for instance, in John B. Scott's otherwise brilliant study: Images of Nepotism. The painted ceilings of Palazzo Barberini (Princeton I99I).

${ }^{8}$ See my discussion of the problem: Rietbergen, Pausen, o.c., chapter II.
} 
that, in a variety of forms, continues to exist in many present-day sociopolitical structures, whether they be monarchical or presidential, and, moreover, irrespective of whether they exist within a democratic or a totalitarian society.

The very fact that even a contemporary observer, the Roman diarist Giacinto Gigli, was able to look back on Urban's pontificate as divided in two periods, the first half dominated by a still strong-willed pope, whose mind and body were fully attuned to the many exigencies of his role, and the latter part, when his age began to tell, by his nephews, shows the effects, according to some even the inevitability of the underlying structure. ${ }^{9}$ As so many of his predecessors, Urban, while still in his prime, deeply felt the need for trustworthy collaborators who, in a culture that was family-centred, could not but be his closest relatives, because early modern European society still was dominated by the concept of "pietas", family piety. The sheer extent of his duties was daunting and the vision of a God-given task, unequalled on earth, must have created tensions and, in the end, great loneliness. Subsequently, as an ailing potentate he could not simply remove his relatives from the positions of power he had given them without undermining his own position.

Of course, the financial consequences of Urban's nepotism have been huge, in terms of the money spent on his relatives, money some saw as the legitimate property of the Church and the Papal States rather than as the pope's private purse though, of course, all European princes considered their state income as their own treasury as well. Again, however, we have to understand that the material support of one's family was generally accepted and even applauded as part of the concept of "munificentia". In a prince, it was a duty that had to be fulfilled on a truly princely scale, resulting, also, in his "magnificentia" that, in itself, was an instrument of (the representation of) power.

Nevertheless, in the case of the Barberini, many considered papal expenditure on behalf of his relatives to have been excessive indeed. Even Urban himself became aware of this when, during his last years, his almost constant illnesses forced him to consider his imminent death, and he started to doubt the choices he had made in this respect. However, one may well ask what was the effect of the reassuring words spoken to him by the committee of cardinals and lawyers he then

\footnotetext{
${ }^{9}$ See the Prologue to the present study.
} 
appointed to look into the theological and moral issues involved. Though they did find a legal justification that would exonerate him, it may not have really convinced him. ${ }^{10}$

Still, the initial jealousy always generated by a family's sudden rise to great wealth and power - as was the essence of the papal elective monarchy - accounts for the heavy criticism Urban came in for as much as, with the passing of the years, the unusual length of his papacy. For the latter resulted in the increasing impatience of persons and factions waiting to take over the reins of power and proceed to the division of the spoils. Also, the pontificate's end in military and financial failure brought about more by the Barberini family's arrogance than by reasons of state contributed to a negative verdict on what, during Urban's lifetime, had been hailed - admittedly by papal adulators - as the 'golden age of the Barberini'. ${ }^{11}$

Meanwhile, it is necessary to consider critically the variety of uses to which the wealth of papal families was normally put: the acquisition of extensive landed property and numerous shares to create a family capital did, of course, little to represent the power of the papacy on the "theatrum mundi". However, the construction of sumptuous family palaces and villas did show the munificence and magnificence of papal power on a more public scale; for though the people who actually enjoyed these dwellings were a small group, only, still these were, in many ways, public buildings, whose effect on the populace at large should not be underestimated. The publication of minor and major works of learning and literature, the commissioning of great works of visual art and the patronage of music definitely benefited a large readership, public and audience. And, of course, the funding of charity as practised in Rome - on a far grander scale than by contemporary secular monarchies, for in line with the demands of Christianity as it was then understood - actually helped keeping thousands of people alive. If one were to argue, following the politically correct tone of many a modern scholarly study, that all this first and foremost served the aim of family aggrandizement and glorification and, thus, the propagation and prolongation of personal or family power, one should realize that

${ }^{10}$ J. Grisar, 'Päpstliche Finanzen, Nepotismus und Kirchenrecht unter Urban VIII', in: Miscellanea Historiae Pontificiae VII (1943), 237-252.

${ }_{11}$ Among many other contemporary references: C. Sarbiewski, Aureum Saeculum Urbani VIII P.O.M. orbi invectum Anno MDCXXIII, a manuscript poem in: Biblioteca Apostolica Vaticana (BAV), Manoscritti Barberiniani Latini (BL), Vol. 2105, fols. I-9. 
it also served the power of the early modern Church as it envisaged its role, in Europe and the wider world. Thus, the papal presence in early modern Rome presents itself as a system of power/culture, a system of great complexity and sophistication that should not be judged on one account only, nor with the facile use of norms alien to its time.

There is yet another plane on which to look at the problems posed by an interpretation of culture in Rome at the end of the i6th and during the early decades of the I 7 th century.

To most people, the period of the Barberini will be almost synonymous with the so-called Baroque Era. Other names, such as Bernini and Borromini, will come to mind, invoking an image of grandiose works of architecture, painting and sculpture that, in their consciously contrived interdependence, tried to achieve "the unity of the visual arts". ${ }^{12}$ Yet, precisely this point needs to be elaborated. I feel that (the) Baroque, far more than being a 'style of art', only, was a style of living and, moreover, a style of living wherein all elements of life were fundamentally united. For besides the bees and the Barberini, it was, also, banquets and behaviour and books, and so much else. Hence, I would argue that Baroque should be the name given to the complex set of phenomena, i.e. to the culture that was the expression of life in European society in the decades following the Council of Trent, ${ }^{13}$ when Reform Catholicism in its centralizing, Roman version reigned supreme. ${ }^{14}$ Indeed, the unity expressed in the epithet 'Baroque' initially derived from that very fact: it owes its existence to the fundamental, indeed existential role played by (Roman Catholic) Christianity as the synthesizing element in the days and works of most European people.

In defining Baroque as a culture one may, I think, compare it to Romanticism, as the two seem to share various characteristics, up to the point that they were both based on religion, on a sense of the fundamental relationship between the natural and the supernatural world; indeed, both tried to preserve that religion against the onslaught

\footnotetext{
${ }^{12}$ I. Lavin, Bernini and the Unity of the Visual Arts (New York 1980).

${ }^{13}$ I go beyond the analysis proposed by the author who wrote one of the most perspicacious studies to date on the phenomenon: J. Maravall, Culture of the Baroque. Analysis of a Historical Structure (Minneapolis 1986), esp. 58, unless one wants to read my 'culture' for his 'structure'.

${ }^{14}$ One should refer here to the long-neglected essay by: Ch. Dejob, De l'influence $d u$ Concile de Trente sur la littérature et les beaux arts chez les peuples catholiques: essai d'introduction à l'histoire litteraire du siècle de Louis XIV (Paris I884).
} 
of what, to many people, were new ideas, new values that seemed to undo Christianity's essential validity. But whereas Romanticism tended to stress Man's private self, and allowed, even encouraged him to project it onto society at large, Baroque was a culture that sought to express his public face, stressing and facilitating his integration in a strongly normative society, indeed, forcing his emotions to conform to and, thus, confirm the norms of that society.

The above reflections that are the basis for the hypotheses and interpretations that underlie my analysis of the various cases presented in this book yet need to be refined.

Some people might argue one should never try to explain a period in monocausal terms, only. Yet, in retrospect, a certain time always will be known by a small number of dominant cultural characteristics. To me, Baroque culture, defined as the culture of Rome - and of those parts of Europe influenced by Rome - between the last decades of the I6th and the last decades of the i 7 th century, can be characterized as follows.

Any complex society with its inevitably attendant complex economy will become manifest in forms of culture that somehow tend to be related to the central question of control, of power. ${ }^{15}$ Especially if the power structures are not legitimised by and founded on institutions based on some sort of consensus involving Man's free will, or the fiction of it, the dominant institutions will have to marshal all available means to manipulate man's head and his heart, the workings of his conscious mind and of his subconscious desires. In a society like papal Rome, the dominant institution was, of course, the Church, in its most visible manifestations, the papal court, the Curia, the aristocracy of 'The City' and the Papal States, the religious Orders. The persons or groups who had a stake in these institutions needed to make sure they retained their power, while those who felt they were put or kept outside the corridors of that power sought possibilities to regain or acquire it. Both ends involved the deployment of cultural policies, of propaganda that could reach ears and eyes, that could shrewdly influence both the intellect and the senses; strategies of rhetoric were the means to these ends, both tapping from the sources of public ideology and of internalised private emotions that had become beliefs, and at the same time reinforcing them. For power needed to be stated, to be made present, to be enacted

15 M. Mann, States and Liberties (London I994). 
in public. Not surprisingly, in many contemporary texts, Rome was likened to a stage, and the persons and groups enumerated above were considered actors, playing the role dictated by their functions on the stage, in the theatre of power that was the world, human society.

Consequently, the increasing stylisation of every form of (public) behaviour, which dressed even the most mundane aspects of daily routine in forms of ceremony and ritual, obviously was a reflection of this vision of Man's presence on the stage of the world's theatre. But, on a deeper level, it was the outward, stage-like manifestation of a growing need for control - control of people's actions but, of course, also of the thoughts whence these actions sprang. After the relative freedom of the preceding age, 'Baroque' society, which, of course, means the groups that dominated that society, represents itself in a culture that reflects a mentality of control.

The cultural change expressed in and brought about by the Catholic Reform movement as codified in the tenets of Trent was, if not the only, surely one of the most profound forces in a society wherein religion still was, or pretended to be the foundation and touchstone of Man's life. In the latter half of the i6th and the first decades of the i7th century, the bases of the Church's power - an economy properly functioning, a society religiously and therefore culturally homogenous - were being gradually eroded. The groups exercising power felt a stronger need for control, but yet could not conceive of any other means than the ones provided by religion as the central ideological framework of both individual and society. Perhaps the manifold manifestations of Baroque culture, most of which ultimately derived from religion as a system of values and a power structure, can be interpreted as the results of a struggle for those values and that power. It was a struggle affecting both the elite and the masses, to use this obviously ideal-typical dichotomy. Hence, the cultural manifestations that were the outcome of as well as the very weapons used in this struggle affected not only the domain of the socalled 'great tradition', the world of the literate, wherein transmission of culture, of ideas often used the cosmopolitan language of learning, of a learning, however, that was always coined by religion; it also triggered reactions within the 'small tradition', the world of the illiterate, spatially and mentally enclosed in largely local communities wherein, however, official religion i.e. Christianity, and its many varieties were the language of power as well.

Obviously, the power elites, too, could not but act within the norms they themselves helped set. For they were the protagonists on the stage, 
having to exemplify, at least in their public life, the morals and virtues held up as norms and guidelines to society at large. Equally obviously, this could not but result in tensions, if only because elites, out of a need to test the extent of their power, always tend to explore the limits of the very norms they themselves impose.

Given the changes in 2oth-century Western culture, it is increasingly difficult to uncover and visualize the vitalizing interaction between the various elements of 'Baroque' life, within the power systems that characterized papal Rome, if only because many present-day observers cannot even begin to understand that Christian religion really was the unifying factor determining and structuring daily routine in all its aspects, Man's actions through all his thoughts. Moreover, there is a definitely dangerous tendency in contemporary historiography, viz. to know the past better than it knew itself, more specifically by using the methods of cultural sociology and social anthropology. ${ }^{16}$ Indubitably, the social sciences have developed concepts that are helpful in focusing the attention of historians largo sensu on topics and patterns of past life that have been neglected or even unsuspected. Yet, they sometimes misleadingly construct the past as a country by and large inhabited by people whom they 'accuse' of, e.g., seeing a religious procession as the festive celebration of the presence of Christ or the saints instead of seeing it as the complex iconography of power it 'really' was. ${ }^{17}$

Rather, I feel there is no satisfactory answer to the question some, or perhaps even many readers will ask. Was power a means to religion, or religion a means to power? Or, to phrase the problem otherwise: was power a means to an end, or was it an end in itself? Regarding the protagonists in this book-Pope Urban VIII, Cardinal Francesco Barberini - if not, perhaps, the host of people surrounding them, employed by them - I feel that, using all the powers within their reach, they sought a fusion of mind and heart to effectuate the ultimate goal, man's union with God.

Those who decide to study 'Baroque society' soon discover that up till now some of its main problems have been best addressed by scholars of

\footnotetext{
${ }^{16}$ For a criticism of contemporary practice: T. Assad, Genealogies of Religion: Discipline and Reasons of Power in Christianity and Islam (Baltimore 1993).

${ }_{17}$ As, for example, in: M. Rubin, Corpus Christi. The Eucharist in Late Medieval Culture (Cambridge 1993).
} 
the visual arts. Increasingly, however, research into i7th-century Roman society has involved the increasingly cooperative efforts of many disciplines. Among them, art historians, musicologists and students of theatre history have been especially productive. And yet it seems most scholars have tended to stop before what, to me at least, is the central question. With often amazing acuity and perspicacity they have tried to analyse the various forms of culture that were produced by this society, and effectively constituted it, but while we now know far more about the rhetorical strategies employed in Baroque cultural production, i.e. about the forms of the message, we still know little about its content, about the groups it tried to reach and, finally, about its effects. These are issues that need to be addressed. However tentatively, the following, more specific considerations hope to do so.

Even the expressions of the visual arts, seemingly so free and exuberant, were nothing if not the expression of and the medium to effectuate highly controlled emotions which, consequently, would result in desired action. Not surprisingly, the written programs for or comments on these manifestations often use the term 'force'. The spectator, through immersion in a visual discourse often reinforced by, and embedded in well-tuned verbal and musical settings, was pleasantly but nonetheless forcefully guided towards the one intended message. Though this message and, indeed, its forms might differ from patron to patron and, hence, from chapel to chapel, from church to church, indeed, from one public space to another, its intention - the power it sought to effectuate - was to never leave the spectator free to 'decide' for himself. What applied to the visual arts, held good for the other ones, too: for the theatre proper, for music, for poetry. It also held good for properly, i.e. controlledly and controllably using food, for the arts of the kitchen. It even held good for the art of proper behaviour, both the behaviour of daily routine and the behaviour of wooing and dying.

Moreover, in giving material form to this message, the producers of culture were far from free themselves. If not consciously guided by formalised treatises or programs specifically written for the occasion, subconsciously they always worked within the cultural confines of a society as set by a 'worldview' that, through its specific cultural signature, steered their emotions and actions.

Especially the patronage involved in the more spectacular manifestations of Baroque culture was, in its very act, an act of power. It showed both the "munificentia" and the "magnificentia" of the patron that were considered part of the proper behaviour of a powerful per- 
son. It consolidated his hold over the artists who were instrumental in visualizing it. But most important, the content of the products this magnificent munificence generated - a palace, a picture or a poem, or, for that matter, a piece of marzipan table decoration - created, through its form, an emotional rapport with the spectator. It sent a message that often was interpreted within a very precise context of power and thus became a stimulus towards desired, specific, proper behaviour, whether experienced and acted consciously or subconsciously.

As I indicated above, historians often tend to assume their analyses reveal structures of thought and action in past societies of which contemporaries had no knowledge or awareness - or so they think. Obviously, they are almost always mistaken. Gabriele Paleotti (I522-I597), cardinal-archbishop of Bologna ${ }^{18}$ not the first but perhaps the most influential theorist of Tridentine religious art and, hence, one of the most influential strategists of propaganda for the Church's power, knew exactly how man's mind worked, how society functioned, and what one should do to make the medium carry the message. To him, beyond the written text, it was the spoken word but even more the visual image that were the most influential information carriers. Consequently, he had thought deeply about their use in society.

To contextualize his treatise on the uses of religious art, Paleotti structured (late i6th-century European) society according to four not entirely distinct categories. The first were the "spirituali", the clergy at large, who dominated if not controlled most instruments of power, not only in the Papal States. The clergy were not necessarily identical with the second group, the "letterati", the ones who could be reached through a culture of learning, the culture of the written and, lately, the printed text; obviously, besides the increasingly important world of scholars, this group also included the literate members of the nonclerical elites, both the old nobility and the Church-related bureaucrats, the new arrivals on the stage of power, as well as the not very numerous professionals. The third section of society thus divided were the "idioti", those who could neither read nor write; except in a few countries,

18 G.B. Paleotti, Discorsi intorno alle imagini sacre et profane ... raccolte e poste insieme ad utile delle anime per commissione di monsignore illustrissimo ... cardinale Paleotti (Bologna I582). A Latin version was produced in I599: Idem, De imaginibus sacris et profanis illustri libri quinque, quibus multiplices earum abusus, iuxta sacrosancti Concilii Tridentini decreta deleguntur (Ingoldstadt 1599). The I582-version is, with other treatises on art, reproduced in: P. Barocchi, ed., Trattati d'arte del Cinquecento fra Manierismo e Controriforma (Bari I96I), Vols. I-II. On Paleotti's life: P. Prodi, Il Cardinale Gabriele Paleotti (Rome I959), Vols I-II. 
they were the majority of Europe's population, for some 75 per cent of males and some 85 per cent of females never mastered these skills. Last, but not least, there were the "pittori", those who could be employed to give a pictorial or indeed in any sense representational form to the message, an adequate form that is, tuned to the group or groups one intended to reach. Though Paleotti did not himself widen the scope of his treatise to cover other mediums of propaganda, of the (re-)presentation of power than painting, I think for "pittori" one must also read: architects, musicians, poets, preachers, indeed every artisan whose craft could be used to create forms able to convey messages: moreover, the "letterati" themselves inevitably came to belong to the group of 'image builders'.

In Paleotti's highly perceptive and shrewd analysis, one thing stands out. Whoever the producer or the consumer, the strategy was always the same. Using such terms as "muovere" and "delectare", "docere" and "insegnare", he argues one should make certain to reach people's hearts. By 'moving' or 'enticing' them with all available 'affective' means, one will 'effectuate' instruction into desired behaviour, into controllable action. The means may differ according to the group addressed. The common folk should not be approached with the intricate arguments of the learned; allegory and mythology are not their language; affectively effective forms, aided by speaking colours - again I feel we may read: sounds, and gestures - will convince them. Sometimes, of course, the simple display of massive wealth through glitter and gold will do the trick. But in the end, whatever the means, the control of emotions will result in a situation wherein emotions facilitate control. According to Paleotti, the public can be 'forced' to accept the power of the Church, the power of religion. Indeed, they must be forced to do so.

In early i7th-century Rome, where, for example, Pope Urban's own public orator and professor of rhetoric Agostino Mascardi wrote a treatise on the many ways people's feelings could be moved, ${ }^{19}$ the powersthat-be tried to direct these 'forces'. Using every available form of culture - as produced, on their instigation, by the "pittori" largo sensu they sought to strengthen their power within the wider society: amongst the "spirituali", the "letterati" and, of course, the "idioti". This resulted in a process that fostered cross-fertilization between the various forms

19 A. Mascardi, Romanae Dissertationes de affectibus... animi earumque characteribus (Rome I639), dedicated to Cardinal Francesco Barberini. 
of culture to create one powerful, all-encompassing emotion - a truly Baroque culture. While stimulating cultural continuity, the process also facilitated cultural change. This book, analysing this process through a series of interrelated cases, will, I hope, help us better understand the relationship between religion and power through the means of the cultural policies pursued by the Barberini. 